\title{
Mitigating Fraud Risk in Cash-Based Payment System via E-Payment Implementation: Case of Indonesia
}

\author{
Machmudin Eka Prasetya ${ }^{1, *}$, Intan Salwani Mohamed ${ }^{1}$, Shuhaida Mohamed \\ Shuhidan ${ }^{1}$, Gede Harja Wasistha ${ }^{2}$ \\ ${ }^{1}$ Accounting Research Institute, Universiti Teknologi Mara, Shah Alam, Malaysia \\ ${ }^{2}$ Department of Accounting, Universitas Indonesia, Jakarta, Indonesia \\ *Corresponding author.Email: machmudin@ui.ac.id
}

\begin{abstract}
E-payment systems, also known as cashless payment systems, have gradually started to replace traditional payment systems. An e-wallet is an innovative cashless payment system that could make transactions more effective and efficient and could mitigate possible fraud risk in cash-based payment systems. This study intends to highlight the potential of e-wallets in mitigating fraud risks in payment systems. This study employs an iterative review of the literature and publications that are relevant to e-wallet and fraud mitigation in payment systems. Based on the analysis, the conclusion reached is that the e-wallet system could reduce the possible risk of fraud occurrence in cash-based payment systems.
\end{abstract}

Keywords: E-Payment, Cash-Based Payment, Fraud, Risk, Fintech

\section{INTRODUCTION}

Current advancements in technology have reached the point of providing ease and convenience for humans engaged in day-to-day activities. The evolution and achievement of technology itself has changed the way that people engage in not only daily activities but also business activities. Many business units have begun to consider acquiring technologies to support their business activities.

Another invention that forms the basis of what we know now as an information technology revolution is the Internet revolution. Leiner et al. (2009) stated that the Internet revolutionized the computer and communications world in a unique manner and gave a new perspective to prior inventions, such as the telephone, the radio, the TV, and the computer. The Internet itself has undergone a revolution from the 1960s until today, generating many more inventions that we know as the web revolution, the mobile revolution, and the digital revolution (Turban, Volonino, \& Wood, 2015). The terminology includes e-commerce, mobile commerce, cloud computing, big data, digital economy, and - the last, a trending topic today-disruptive technology.

The emergence of e-commerce/mobile commerce has created other innovations in financial technology (fintech) for not only an official financial institution such as a bank but also other non-bank financial institutional forms. Fintech has created innovations such as Internet banking, mobile banking, and other epayment systems - e-credit cards, e-cash, and e-wallets (Rainner \& Cegielski, 2011).

\section{PAYMENT SYSTEM}

\subsection{Traditional Payment System}

Initially, payment systems in the early days were a consequence of executing transactions. In the past, until money was invented, transactions were done through a bartering system. According to Blakstad et al. (2018), money is a tool designed to make the exchange process easier than a bartering system. Up until now, money consists of coins and notes. This type of payment was known as a cash payment system/traditional payment system. 
According to Dahlberg (2006), payment is defined as the transaction process through which funds are transferred from the payer (buyer, transmitter of funds) to the payee (seller, receiver of funds) directly or through an intermediary. Payment transactions are carried out using payment instruments.

\subsection{E-Payment System}

Along the way, the payment system was transformed into innovations, such as credit cards in the 1950s, automatic teller machines (ATM), and debit cards in the 1980 s, e-commerce in the 1990s, and e-payment systems as the current innovation (Scardovi, 2017), which is included as a fintech innovation. Forms of epayment systems include e-credit cards, e-cash, and ewallets (Rainner \& Cegielski, 2011).

This type of payment system has gradually started to replace the traditional payment system. An e-payment system is somehow known as a cashless payment system (Scardovi, 2017) in a cashless society.

\section{E-PAYMENT SYSTEM IN FINTECH}

As previously mentioned, fintech, which emerged in the last ten years, has become the innovation in the financial industry. According to Lee and Shin (2018), fintech has rapidly emerged, driven in part by a sharing economy, favorable regulations, and information technology.

Fintech provides new opportunities by increasing transparency, reducing costs, creating disintermediaries, and making financial information accessible (Zavolokina, Dolata, \& Schwabe, 2017). This innovation was exposed to not only the banking industry but also started to involve non-banking industries. Many startup companies got involved in fintech.

Fintech consists of several types of businesses. Lee and Shin (2018) stated that typical types of fintech are payment systems, wealth management, peer-to-peer lending, crowdfunding, capital markets, and insurance fintech companies. The two largest types of fintech in Indonesia are payment systems (38\%) and peer-to-peer lending (31\%) (fintechnews singapore, 2018).

An e-payment system can consist of credit cards, debit cards, Internet banking, mobile banking, and $e$ money/e-wallet (Rainner \& Cegielski, 2011). The first three are typically produced by the banking industry, and the last one is produced today by both the banking industry and non-banking industries. An e-wallet or digital wallet is available in a mobile phone or personal computer: "money is loaded from the bank account using a debit/credit card or Internet banking to make payments to people/merchants using the same wallet, therefore giving a comfortable cashless method" (Bagla \& Sancheti, 2018).

\subsection{Fraud in Payment Systems}

\section{Fraud in Information Technology}

Fraud is defined as "any and all means a person uses to gain an unfair advantage over another person" (Romney and Steinbart, 2018). Fraud occurs in the form of, for example, deception, embezzlement, misappropriation, and corruption. Fraud can occur at the individual or organizational level. Fraud can also occur as an unintentional act or an intentional act (usually known as a computer crime).

Fraud from computer crime can occur because of a software error, operating system crash, hardware failure, power loss, or data transmission error-the more advanced the information technology, the greater the threat of exposure. The application's organization or vendor must have a strong risk management plan to minimize the exposure to threats and fraud. Subsequently, fraud and the threat of exposure of the traditional payment system are explained.

\section{FRAUD IN TRADITIONAL PAYMENT SYSTEM}

Until today, the traditional payment system in the form of a cash payment system has been threatened by exposure and fraud related to transactions.

The risk of using a cash-based payment system are as follows (Kumari, 2017; Meena, 2017):

- Risk of carrying cash. In the past, many robberies occurred when workers' salaries were still paid in cash. A person was appointed to take cash from the bank, and then took the cash to the office to distribute it to all of the workers.

- Cost of carrying cash. A safe deposit box, keys, and other tools are needed to protect the cash from being stolen.

- Exposure to money laundering, corruption, and bribery, which can happen when using cash.

- Increasing crime rate from carrying cash resulting from illegal transactions that primarily use cash, such as human trafficking, the drug trade, money laundering, and others.

- From the merchant's point of view, the cashbased payment system was somehow troublesome, inflexible, ineffective, and inefficient in terms of time.

All of the disadvantages of a cash-based payment system are mitigated by using a cashless payment system, which is further explained. 


\section{THE NEED FOR AN E-PAYMENT SYSTEM IN INDONESIA}

As previously explained, traditional payment systems have many disadvantages. The innovation of information technology, particularly fintech, has led to the change from traditional payment systems to epayment systems, including Internet banking, mobile banking, debit cards, credit cards, and - the most recent innovation-e-money/e-wallet, which represents fintech innovation.

Few studies aimed to identify the effect of using an e-payment system relative to a cash-based payment system/traditional payment system. The studies resulted in some findings and conclusions regarding the use of epayment systems.

Meena (2017) explained the benefits of a cashless society that uses e-payment systems, as follows.

- Convenient mode of payment: an e-payment system is convenient for users and does not include a cost to carry, protect, and hold the funds.

- Lower risk: using an e-payment system comes with minimized risk relative to the traditional payment system/cash-based payment system because of sufficient and appropriate risk management and security from the application vendor. The traditional payment system is exposed to the risk of theft, loss, or damage.

- Decrease in the crime rate: many illegal activities, such as selling drugs, human trafficking, and money laundering, typically use a cash-based payment system.

- Transparency and monitoring: an e-payment system offers transparency of the transaction traffic within society, and the government can monitor the system to prevent illegal activities, such as tax avoidance, money laundering, and corruption. The system detects abnormal transactions.

From the merchant's point of view, the benefits of an e-payment system somehow reduce the handling of cash and queuing at stores (Clark, 2005).

Kumari (2017) stated that the following objectives of being cashless.

- Modernization of payment system: an efficient epayment system results in the development and growth of economics.

- Efficient transactions: an e-payment system reduces the cost of the banking system and leads to the financial inclusion of unbankable citizens.

- Reduce the high cost of cash: the cost of cash includes the cost of carrying and holding cash.
- Reduce the high risk associated with cash: the cost of holding cash includes being robbed and facing other cash-related crimes.

The emergence of an e-payment system initially aimed to increase efficiency and effectiveness and reduce risk and fraud in payment transactions (Dahlberg, 2006; Hamdi, 2011; Hayashi \& Bradford, 2012). At first, these objectives can be achieved through the aid of the tools/channels from ATMs, Internet banking, and mobile banking (Aishah Mohamad \& Kassim, 2017).

The latest e-payment system technology is included in fintech. Fintech creates the opportunity to increase transparency, reduce costs, and make information more accessible for all users (H.-S. Ryu, 2018). Gupta and Xia (2018) also stated that fintech gives users a better customer-based banking system, reduces the risk and fraud that users face, and increases returns to all shareholders.

However, users are still becoming aware of using the current e-payment systems because they continue to worry about the security and privacy of their data. Epayment vendors are required to do their best when investing in securing user data. Vendors must strengthen their cybersecurity framework to minimize the risk of fraud (Stewart \& Jürjens, 2018).

\section{Trends in E-Payment Systems in Indonesia}

For Indonesia, investments in fintech reached US\$176.75 million as of 2017 (fintechnews singapore, 2018). This tremendous growth clearly reveals the future potential of the fintech market. In contrast, the banking system has put most of its IT investments $(86 \%)$ into mobile banking and smartphone-based application and collaboration (46\%) with fintech companies (PwC Indonesia, 2018). This collaboration occurs through the growth in payment systems from fintech companies.

Regarding statistics on e-payment systems in Indonesia, the Indonesia Central Bank website (www.bi.go.id) indicated that the number of e-wallet/emoney accounts in use was $173,825,919$ as of January 2019. Assuming that every user owns at least two ewallet/e-money accounts, the number of e-money users is approximately 86 million. In other words, given that the total population of Indonesia has reached 265.4 million (wearesocial.com, 2019), approximately 33\% are e-wallet/e-money users.

The number of e-money/e-wallet transactions has increased over the years (www.bi.go.id, 2018), as illustrated in Figure 1. 


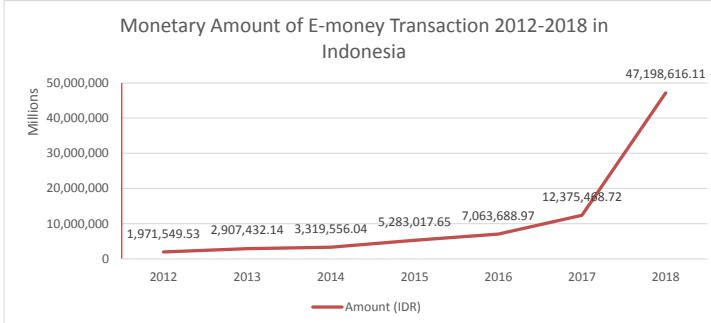

Figure 1. Monetary Amount of E-Money Transactions in Indonesia during 2012-2018 (source: www.bi.go.id).

In Figure. 1, the slope is steeper in 2017-2018 because of the mandatory use of e-money for highway toll payments in Indonesia.

As previously explained, debit and credit cards are included in the e-payment system. Their use is experiencing an increasing trend, similarly for e-money transactions, as indicated in Figure. 2 and 3.

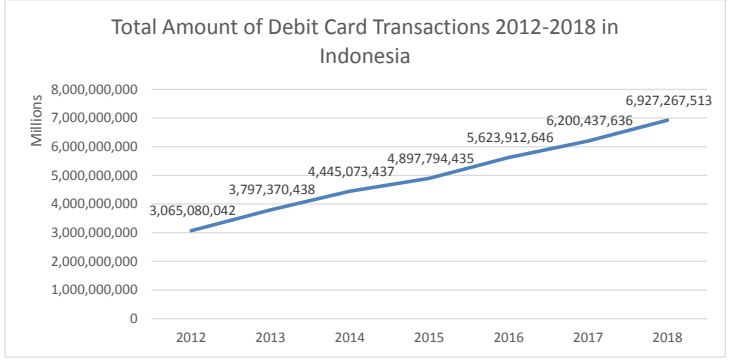

Figure 2. Total Amount of Debit Card Transactions in Indonesia during 2012-2018 (source: www.bi.go.id).

Total Amount of Credit Card Transactions 2012 2018 in Indonesia

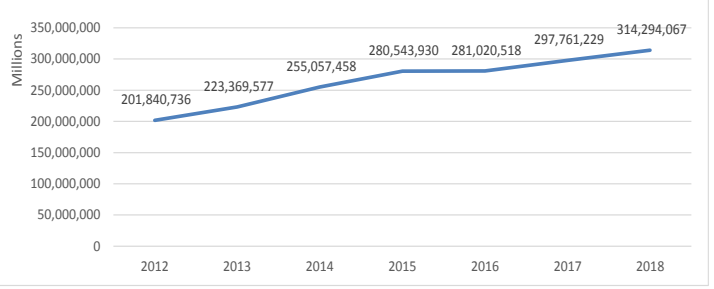

Figure 3. Total Amount of Credit Card Transactions in Indonesia during 2012-2018 (source: www.bi.go.id).

Other facts that were accurate as of July 2019 are as follows. Thirty-eight e-money vendors-both cardbased and application-based e-wallet/e-money vendors-received certification from the Indonesia Central Bank, and other vendors are in the process of being certified. All of these facts reflect the huge potential market for e-payment systems in Indonesia, even though the number of e-wallet/e-money users is still low. A gap exists between the supply and the demand from users, which requires an explanation. Previous studies such as from (H. S. Ryu, 2018; Stewart \& Jürjens, 2018) found that potential users were still concerned with the security and risk management of this new technology.

\section{DOES AN E-PAYMENT SYSTEM MITIGATE FRAUD IN TRADITIONAL PAYMENT SYSTEMS}

The previous section explained that the aim of epayment systems is to increase efficiency and effectiveness and reduce risk and fraud in payment transactions (Dahlberg, 2006; Hamdi, 2011; Hayashi \& Bradford, 2012).

An indicator is needed to prove the effect of using and implementing e-payment systems, especially in Indonesia. This paper uses statistics on crimes as published by the Central Bureau of the Statistic Republic of Indonesia as a proxy for the mitigation of the fraud caused by e-payment systems. The number of crimes against rights/property in Indonesia involving violence is indicated in Fig. 4. The number of crimes against rights/property in Indonesia that did not involve violence is indicated in Figure 5.

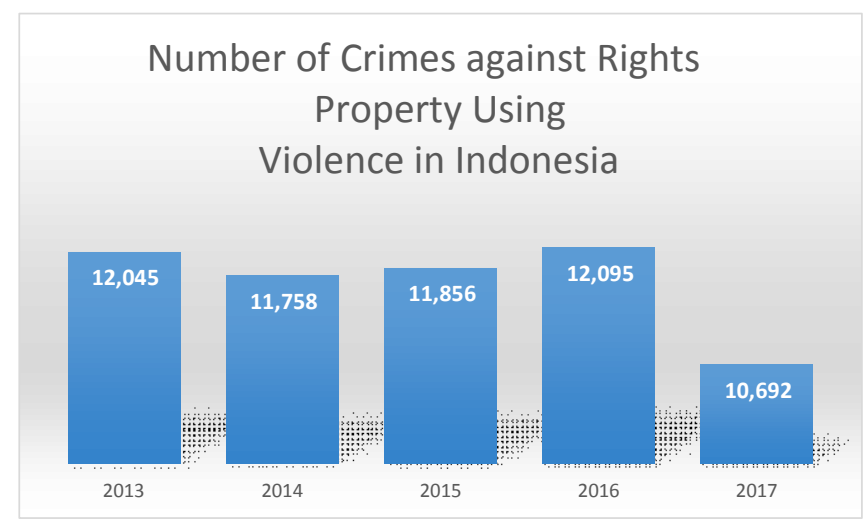

Figure 4. Number of Crimes against Rights/Property Involving Violence in Indonesia (Source: Central Bureau of Statistics Republic of Indonesia. 2018).

\section{Number of Crimes against Rights Property Using Violence in Indonesia}

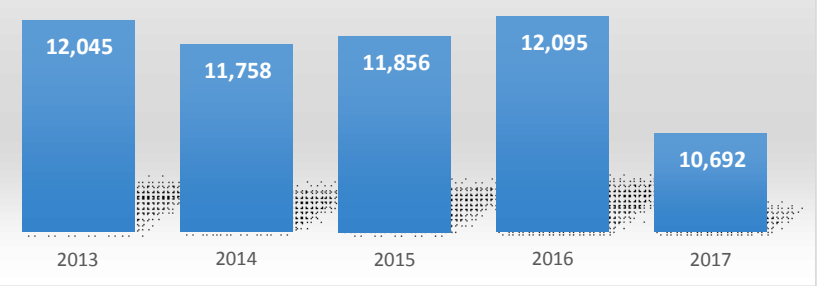

Figure 5. Number of Crimes against Rights/Property Involving Violence in Indonesia (Source: Central Bureau of Statistics Republic of Indonesia. 2018)..

Figures 4 and 5, although approximate, indicate that the crime level from these two categories decreased from 2013 to 2018. These two categories were selected as a proxy because of the inclusion of robbery, 
pickpocketing, and other types of crime that have the consequence of losing cash.

This study leads to the conclusion that an increase in e-payment system usage is followed by a decrease in the crime rate related to the traditional cash-based payment system. Further study is required to confirm this conclusion. The cause of the decreasing crime rate might involve other factors instead of only the increasing use of an e-payment system.

\section{CONCLUSION}

This section summarizes the discussion and findings on the comparison of e-payment systems and cash-based payment systems. Few previous studies mentioned the disadvantages of traditional payment systems that used cash-based payment systems, and the emerging epayment systems aim to overcome these drawbacks and, eventually, make payment systems more efficient and effective.

This objective can be achieved given all of the support for e-payment systems, which are well prepared; users need to be convinced to use these systems. Previous studies concluded that e-payment systems are accepted.

This paper has limitations, given that only the epayment system phenomenon in Indonesia was discussed. Further research can be conducted to confirm the premises that were concluded in this paper and previous studies.

\section{REFERENCES}

[1] Aishah Mohamad, S., \& Kassim, S. (2017). An Overview of E-Payment Adoption Among Muslim Micro-Entrepreneurs in Malaysia. International Journal of Accounting Finance and Business, 2(5), 49-59. Retrieved from http://www.ijafb.com/PDF/IJAFB-2017-05-0905.pdf

[2] Bagla, R. K., \& Sancheti, V. (2018). Gaps in customer satisfaction with digital wallets: challenge for sustainability. Journal of Management Development, 37(6), 442-451. https://doi.org/10.1108/JMD-04-2017-0144

[3] Blakstad, S., Allen, R., Blakstad, S., \& Allen, R. (2018). The Money Revolution: Recycling Value to Drive Sustainability. FinTech Revolution, 167181. https://doi.org/10.1007/978-3-319-76014$8 \_10$

[4] Central Bureau of Statistics Republic of Indonesia. (2018). 2018 Indonesia Criminal Statistics. Retrieved from https://www.bps.go.id/publication/download.html? nrbvfeve $=$ ODljMDZmNDY1Zjk0NGYzYmUzOT AwNmEx\&xzmn=aHR0cHM6Ly93d3cuYnBzLm dvLmlkL3B1YmxpY2F0aW9uLzIwMTgvMTIvMj YvODljMDZmNDY1Zjk0NGYzYmUzOTAwNm ExL3N0YXRpc3Rpay1rcmltaW5hbC0yMDE4Lm h0bWw\%3D\&twoadfnoarfeauf=MjAxOSOwN

[5] Clark, C. L. (2005). Shopping Without Cash: The Emergence of The E-Purse. Economic Perspectives, 34-51. Federal Reserve Bank of Chicago.

[6] Dahlberg, T. (2006). Understanding Changes in Consumer Payment Habits-Do Mobile Payments Attract Consumers. Proc of the Global Mobility Roundtable, Helsinki, (June), 1-13. Retrieved from http://sprouts.aisnet.org/6-

36/\%5Cnhttp://scholar.google.com/scholar?hl=en\& $\mathrm{btnG}=$ Search\&q=intitle:Understanding + Changes $+\mathrm{i}$ $\mathrm{n}+$ Consumer+Payment+Habits-

Do+Mobile+Payments+Attract+Consumers?\#3

[7] fintechnews singapore. (2018). Fintech Indonesia Report 2018 - The State of Play for Fintech Indonesia | Fintech Singapore. Retrieved March 11, 2019 , from http://fintechnews.sg/20712/indonesia/fintechindonesia-report-2018/

[8] Gupta, A., \& Xia, C. (2018). A Paradigm Shift in Banking: Unfolding Asia's FinTech Adventures. https://doi.org/10.1108/s1571038620180000025010

[9] Hamdi, H. (2011). Can E-Payment Systems Revolutionize Finance of the Less Developed Countries? The Case of Mobile Payment Technology. International Journal of Economics and Financial Issues, 1(2), 46-53.

[10] Hayashi, F., \& Bradford, T. (2012). Mobile Payments: Merchants' Perspectives I. PAYMENT ENVIRONMENT AND MOBILE PAYMENT TECHNOLOGIES, 33-58. Retrieved from https://www.kansascityfed.org/XdNVZ/publicat/ec onrev/pdf/14q2Hayashi-Bradford.pdf

[11] Kumari, N. K. J. (2017). Cashless Payment: A Behaviourial Change to Economic Growth. Qualitative and Quantitative Research Review.

[12] Lee, I., \& Shin, Y. J. (2018). Fintech: Ecosystem, business models, investment decisions, and challenges. Business Horizons, 61(1), 35-46. https://doi.org/10.1016/j.bushor.2017.09.003

[13] Leiner, B. M., Clark, D. D., Kahn, R. E., Kleinrock, L., Lynch, D. C., Postel, J., ... Wolff, S. (2009). A Brief History of the Internet. ACM SIGCOMM Computer Communication Review, 
$39(5)$,

$22-31$.

https://doi.org/10.1145/1629607.1629613

[14] Meena, M. (2017). From a Cash Economy to a Less-Cash Economy. World Wide Journal of Multidiscipl Inary Research and Development WWJMRD, 3(7), 7-9.

[15] PwC Indonesia. (2018). PwC Survey: Digital Banking in Indonesia 2018, (July).

[16] Rainner, R. K., \& Cegielski, C. G. (2011). Introduction to Information System. Enabling and Transforming Business 3rd Edition (3rd ed.). New York: John Wiley \& Sons (Asia) Pte. Ltd.

[17] Romney, M. B., \& Steinbart, P. J. (2018). Accounting Information Systems, 14th Edition (14th ed.). London: Pearson Education Limited.

[18] Ryu, H.-S. (2018). Understanding Benefit and Risk Framework of Fintech Adoption: Comparison of Early Adopters and Late Adopters. Proceedings of the 51st Hawaii International Conference on System Sciences, 3864-3873. https://doi.org/10.24251/hicss.2018.486

[19] Ryu, H. S. (2018). What makes users willing or hesitant to use Fintech?: the moderating effect of user type. Industrial Management and Data Systems. https://doi.org/10.1108/IMDS-07-20170325
[20] Scardovi, C. (2017). Digital Transformation in Financial Services. Digital Transformation in Financial Services, 65-84. https://doi.org/10.1007/978-3-319-66945-8

[21] Stewart, H., \& Jürjens, J. (2018). Data security and consumer trust in FinTech innovation in Germany. Information and Computer Security. https://doi.org/10.1108/ICS-06-2017-0039

[22] Turban, E., Volonino, L., \& Wood, G. R. (2015). Information Technology for Management (10th ed.). New York: John Wiley \& Sons (Asia) Pte. Ltd.

[23] wearesocial.com. (2019). We Are Social - Digital Report 2018. Retrieved March 6, 2019, from https://digitalreport.wearesocial.com/download

[24] www.bi.go.id. (2018). Jumlah Uang Elektronik Bank Sentral Republik Indonesia. Retrieved March 11, 2019, from https://www.bi.go.id/id/statistik/sistempembayaran/uang-elektronik/Contents/Jumlah Uang Elektronik.aspx

[25] Zavolokina, L., Dolata, M., \& Schwabe, G. (2017). FinTech transformation: How IT-enabled innovations shape the financial sector. In Lecture Notes in Business Information Processing. https://doi.org/10.1007/978-3-319-52764-2_6 